\title{
POŽEŠKI PERIOD DRAGUTINA LERMANA
}

\section{Sažetak}

Dosadašnje spoznaje o nepoznatom požeškom razdoblju života i djelovanja Dragutina Lermana do sada su se bazirale isključivo na šturim povijesnim podacima te predgovoru Kreševskih dnevnika „Čovjek koji je vjerovao u svoju sreću“ Zlate Kolarić Kišur.

Pažljivijim iščitavanjem dosad nepoznate građe pronađene u jednoj obiteljskoj arhivi (Lermanovi dnevnici, pisma...), Lermanovih tiskanih dnevnika Afričkog i Krešeuskih, građe koja se čuva u požeškom Muzeju, članaka iz lokalne i nacionalne periodike početkom stoljeća te objavljenih istraživanja Mire Kolar dobili smo puno jasniju sliku o Lermanovim požeškim poslovnim nastojanjima, kao i o obiteljskom životu.

U radu se pojašnjavaju Lermanovi motivi napuštanja uspješne karijere generalnog povjerenika pokrajine Istočni Kwango u Africi te povratka u Požegu.

Jednako tako nastoji se razjasniti lokalna i nacionalna politička i društvena pozadina uspjeha, ali i potpun slom Lermanovih poslovnih pothvata u Požegi te činjenica da je od uspješnog poslovnog čovjeka jedini ostao bez ičega, prognanik iz grada čijem je napretku posvetio velik dio svoga života.

Rad je i poticaj za istraživanje novih izvora koji posebno osvjetljavaju godine Lermanova izgnanstva u Europu o kojima ništa ne znamo te truda da pronađe investitore za propala požeška ulaganja.

Ključne riječi: Dragutin Lerman; Požega; dnevnik; požeški period.

\section{Uvod}

O Dragutinu Lermanu kao afričkom istraživaču Konga, rođenom u Požegi 24. kolovoza 1863., saznajemo ponajprije zahvaljujući sačuvanoj građi u obliku njegovih dnevnika i pisama ${ }^{1}$. O Lermanovu požeškom i kreševskom periodu, dakle onom poslije povratka iz Afrike, znamo vrlo malo, oslanjajući se u istraživanju uglavnom na šture podatke Lermanova prijatelja i kuma Julija Kempfa (Kempf, 2004: 362) te

1 Poznata pisana građa vezana za Lermana čuva se u Gradskom muzeju Požega (Lermanova pisma te dnevnici iz razdoblja njegova boravka u Kreševu (1916. - 1918.)), u Arhivu HAZU, u Franjevačkom samostanu u Požegi te u Franjevačkom samostanu u Kreševu. 
sjećanje suvremenice i obiteljske poznanice, književnice Zlate Kolarić Kišur u obliku romansirane pripovijesti (Kolarić Kišur, 1992: 7-71).

Osnovna svrha ovoga rada jest predočiti Lermanovo značenje za razvoj gospodarstva, posebice rudarstva i industrije, u požeškom kraju.

\section{Razlozi lermanova napuštanja afričke karijere}

Izvjesno je da je Dragutin Lerman svoju uspješnu ${ }^{2}$ trinaestogodišnju afričku istraživačku karijeru završio naglo, i to netom poslije posljednjeg unapređenja 2. lipnja 1896. ${ }^{3}$ Razlozi gotovo naprasnog odlaska nisu zdravstvene prirode, kako navodi Zlata Kolarić Kišur, nego ljubav prema Hedvigi Reiner, kćeri najbogatijeg vlastelina Požeške županije u koju se, po svemu sudeći, zaljubio 1891. godine za vrijeme svog devetomjesečnog zdravstvenog oporavka u Požegi poslije drugog putovanja u Afriku.

Naime, za vrijeme trećeg boravka u Africi, točnije 10. lipnja 1894., Lermanov stric Josip ${ }^{4}$ obavještava Lermana da se pripremaju zaruke Hedvige Reiner. Očito zaljubljen, Lerman $u$ dnevniku reagira vrlo burno nastojeći se na koncu pomiriti sa situacijom vrlo znakovitom rečenicom koja naslućuje izvor njegove potrebe za dokazivanjem u kasnijim požeškim godinama: „Ja sam uostalom vrlo brzo shvatio preveliku razliku društvenog nam, odnosno klasnog položaja, nu srce u čovjeka rijetko sluša razum." (Lerman, 1989: 494)

Znakovito je da se Lermanov „,nenadani“ dolazak iz Afrike 10. listopada 1894.5, poslije trećeg putovanja, poklapa s Hedviginim zarukama s oružničkim časnikom Šandorom Gavranićem koje su bile najavljene za tjedan dana poslije ${ }^{6}$. Zanimljiva podudarnost s raskidom zaruka Hedvige i časnika Gavranića jest i u nizu članaka u Glasniku županije Požeške koji između lipnja, kada je doznao za zaruke, i listopada, za kada su zaruke zakazane, ali i netom poslije, dižu Lermanov ugled promovirajući ga kao znamenitog čovjeka koji se dopisuje s biskupom Strossmayerom, dobiva najviša odlikovanja od belgijskog kralja Leopolda II. te donosi zagrebačkom muzeju niz dragocjenih darova?

2 Svoju karijeru Lerman je gradio na nizu unaprjeđenja i odlikovanja: travanj 1884. - zapovjednik stanice Philippeville, studeni 1884. - zapovjednik stanice Rudolfstadt, 1889. - upravitelj okružja i stanice Stanley Falls, 29. 5. 1894. - odličje viteza Kraljevskog lavovskog reda, 26. 5. 1895. komandant okružja Kwango, 2. 6. 1896. generalni povjerenik istočnog Kwanga, 29. 9. 1896. odličje Zvijezde za zasluge.

3 Imenovanje Dragutina Lermana generalnim povjerenikom, GMP, Inv. broj: 13.639

4 Godine 1878., za vrijeme pohađanja trgovačke škole, Lerman živi šest mjeseci u Budimpešti kod strica Josipa Lermana, visoko odlikovanog kraljevskog ministerijalnog savjetnika, koji mu je poslije bio i vjenčani kum.

5 GŽP 13. 10. 1894.

6 GŽP 20. 10. 1894.

7 GŽP 23. 6, 7. 7., 13. 10., 17. 11. i 9. 12. 1894. 
Zbog trinaest godina starijeg Lermana, Hedvigine zaruke s Gavranićem očigledno su otkazane ili barem vrlo brzo raskinute, pa se on, pun slatkih nada u skorašnju ženidbu, upućuje na svoje četvrto i posljednje putovanje u Afriku koje je trajalo svega nekoliko mjeseci.

Iako tijekom tog četvrtog boravka u Africi dobiva i posljednje, najveće promaknuće $\mathrm{u}$ karijeri u vidu generalnog povjerenika za Istočni Kwango, $\mathrm{u}$ dnevniku je vidljivo da se Lerman zbog Hedvige svim silama ${ }^{8}$ trudi što prije vratiti u Požegu. Svakodnevno joj piše, nestrpljivo očekujući njene odgovore, panično se brine za njeno zdravlje zaduživši mnoge u Požegi da paze na nju. Ne veseli ga ni samo promaknuće kao rezultat iznimno mukotrpnog rada: „Veće mi je veselje učinio list od moje miljenice, koja sigurno niti danas ne vjeruje, da sam na putu doma!“ (Lerman, 1989: 523)

U listopadu se Lerman trijumfalno vraća u svoj rodni grad donoseći usput i posljednji „patriotičan“ dar, ovaj put 40 životinja zoološkom muzeju u Zagrebu'. Krajem istog mjeseca 1896. godine zaručuje se s Hedvigom, kojom se poslije svega šest mjeseci, 28. travnja 1897., i ženi na imanju njezina oca, dr. Mije Reinera, veleposjednika u Brestovcu ${ }^{10}$.

\section{Lermanov povratak u Požegu i uključivanje u društveno-gospodarske aktivnosti}

Činjenica jest da su Lermana i Hedvigu u ono vrijeme, unatoč njegovu dobrom glasu i afričkoj reputaciji, dijelile nepremostive razlike, jer je on bio trgovački pomoćnik, posjednik, sin obrtnika, a Hedviga vlastelinka, veleposjednica, kći najbogatijeg i najutjecajnijeg veleposjednika u Požeškoj županiji11, što je utjecalo na Lermanovu konstantnu potrebu za poslovnim dokazivanjem.

Dva mjeseca prije vjenčanja ${ }^{12}$ Lerman ruši staru obiteljsku kuću preko puta zgrade Financijalnog ravnateljstva u centru grada i za nepunih pet mjeseci, u srpnju, useljava se u novosagrađenu veliku reprezentativnu građansku katnicu ${ }^{13}$. U studenom iste godine pred svojom novom kućom već organizira svečanu bakljadu i serenadu puncu, dr. Miji Reineru u povodu njegova imendana ${ }^{14}$.

8 Dragutin Lerman, Afrički dnevnik, 1. 7. 1896., str. 523. Lerman se nije brinuo zbog naglog pada tjelesne težine kao posljedice malarijske groznice, štoviše - smanjena težina povećavala mu je radnu nesposobnost i otvarala mogućnost za raniji povratak u Požegu.

9 GŽP 24. 10. 1896.

10 Izvod iz matične knjige vjenčanih, prijepis: M-1/155-1982, kopija GMP.

11 Veleposjednik dr. Mijo Reiner godinama je, prema izvješćima sa sjednica Županijske skupštine, svoju fiskalnu godinu završavao kao najveći porezni obveznik.

12 Podatke iz obiteljskog molitvenika dobila sam na uvid 1988. godine ljubaznošću Alme Vinković, pokojne nećakinje Dragutina Lermana.

13 Prema Izvatku iz zemljišne knjige K1 3115/1988 (GMP), bez obzira na brata i sestre, vlasništvo nad kućom prodajom se prenosi u siječnju 1899. godine na Lermana.

14 GŽP 19. 11. 1898. 
Lerman se polako i s prirođenom lakoćom posve uklopio u vrh društvenog života grada Požege. Iako je bicikl naučio voziti u Africi tek nekoliko godina prije (Lerman, 1989: 500), podupirući moderan i zdrav način života, 1899. godine postaje potpredsjednikom Biciklističkog kluba u Požegi ${ }^{15}$ kojemu je predsjednik bio sudac dr. Ladislav Virag, a tajnik novčar Bernard Schwartz, s kojim će ga poslije vezati zajednički poslovni, ali i privatni interesi.

Lermanov punac dr. Mijo Reiner kao jedan od najvećih vlastelina Požeške županije još je 1892. godine osnovao Štednu i pripomoćnu zadrugu (Kempf, 1910: 493), koja se na njegovu inicijativu tri godine poslije, dakle 1895. godine, razvila u Prvu požešku štedionicu d.d., zapravo kreditni zavod vrlo pristupačan i popularan, posebice među pukom (Kolar, 1996: 16). Kako je i sam, doselivši se u Požegu kao doktor kemije, počeo gotovo od nule te uspio zahvaljujući, između ostalog, pomoći i podršci obitelji Thaller u koju se priženio (Kolar, 1996., 26), dr. Mijo Reiner istu je priliku pružio svom zetu Dragutinu Lermanu, kojemu je 1900. godine povjerio ravnateljstvo banke.

Sljedeće, 1901. godine banka izvrsno posluje, pa pod Lermanovim prohrvatski orijentiranim vodstvom, u kontekstu mađaronski orijentirane gradske politike, novoosnovanom Hrvatskom školskom muzeju u Zagrebu namjenjuje četiri puta veći iznos nego Prva požeška štedionica, iako je odnos kapitala bio obrnut (Kolar, 1996: 20).

\section{Reanimacija ugljenokopa Majdan u Ratkovici i širenje opsega poslo- vanja Pučke banke d.d.}

Naravno, Lermanu, koji je razmišljao puno šire i rizičnije od svoga punca, banka je, između ostaloga, predstavljala mehanizam pomoću kojega će osigurati strane ulagače za svoje pothvate i poslovne ideje. Naime, s obzirom na svoje svjetsko iskustvo i poznavanje tekovina industrijske revolucije, Lerman je znao da temelj suvremenog razvoja gospodarstva ovisi prije svega o što jeftinijim energentima, pa je tako nastojao realizirati ideju crpljenja ugljena iz Požeške gore, točnije povijesnog ugljenokopa Majdan iza sela Seovci nedaleko od Požege (Kempf, 1910: 474-475). Upravo je svojim vezama zainteresirao belgijske novčare Društva za studij i razvoj kolonijalnih poduzeća La Coloniel Industriell koji su pristali ulagati u obnovu požeškog rudnika pod uvjetom da desetina kapitala bude domaćeg porijekla. Angažirajući u tu svrhu kapital Pučke dioničke štedionice kojom je ravnao, ali i prijateljske Bankarske radnje Schwartz i Spitzer, Lerman 12. ožujka 1902. osniva Dioničko društvo Ratkovica, odnosno Societe anonymede Carbonnages Ratkovica (Kolar, 1996: 17). ${ }^{16}$

15 GŽP 25. 3. 1899.

16 Svega godinu dana poslije u Glasniku županije Požeške izlaze „Upute za loženje kamenim ugljenom“ s naznakom da „neće proći puno vremena pa će se u našem gradu upotrebljavati ugljen namjesto drva za gorivo.", GŽP 7. 2. 1903. 
Lerman, potpuno otvoren dobrobiti svojih sugrađana, novac Pučke dioničke štedionice koristi i za vrlo povoljne kredite za gradnju novih kuća te obnovu od filoksere postradalih požeških vinograda koji su Požežanima bili dragocjen izvor prihoda. Štoviše, na brežuljku Kapavac ponad samoga gradskog glavnog trga, Lerman je i sam posadio veliki ogledni vinograd.

Svojim zalaganjem za opću dobrobit u gradu Požegi slovi kao čovjek od društvenog povjerenja, pa mu je 1900. godine pripala čast biti ne samo predsjednikom HPD-a Vijenac, u čijem je osnivanju sudjelovao kao osamnaestogodišnji mladić, nego i njegovim počasnim članom. U to vrijeme to pjevačko društvo modernizira pravila i ciljeve, od kojih je osnovno vrlo domoljubno: gajiti hrvatske, slavenske i ine pjesme prevedene na hrvatski jezik u okolnostima mađarizacije i germanizacije (Kempf, 1910: 649). ${ }^{17}$

Godine 1903. Lermanovi se poslovi zahuktavaju. U veljači se pod njegovim ravnanjem održava znakovita glavna skupština Pučke dioničke štedionice, koja mijenja dosadašnje ime u Pučka banka d.d., šireći djelokrug poslovanja, uvodeći mirovinski statut za osiguranje činovnika, osnivajući zakladu na osnovi povećanja glavnice te donoseći nova moderna pravila koja omogućavaju Lermanu lakše poslovanje (manji broj članova ravnateljskog vijeća) te veću kontrolu (povećan broj članova nadzornog odbora) ${ }^{18}$.

Povećanje blagajničkog prometa banke za 6.800 kruna više nego prethodne godine Lermanu daje vjetar u leđa za ulaganje u infrastrukturu ugljenokopa Majdan, a gradi i uskotračnu željeznicu duljine $7,5 \mathrm{~km} \mathrm{~s} 18$ vagona za prijevoz ugljena iz rudnika do željezničke postaje Ratkovica te nabavlja dva parostroja, sve to pod budnim okom ugarskog Ministarstva trgovine koje 30. travnja 1903. šalje svoje Povjerenstvo za nadzor. Već sljedeći dan, 1. svibnja 1903., prvi vlak natovaren ugljenom kreće ispuniti puno vanjskih narudžbi. S vremenom je nabavljena i parna sisaljka te 100 malih vagona za željeznicu pod zemljom. ${ }^{19}$ Sve detalje donosi opširan članak na naslovnici Glasnika županije Požeške uz važnu napomenu da je na tom projektu zaposleno puno ljudi iz okolice kojima će to pomoći u inače teškim materijalnim prilikama. ${ }^{20}$

Da se radi o vrlo ambicioznom i obećavajućem projektu, govore nam podaci da je u krugu ugljenokopa u vrlo kratkom roku sagrađeno 12 zgrada za čak 150 radnika, kojima je uvijek filantropski raspoložen Lerman od Grada Požege osigurao zemljište za njive i šumu za potrebu korištenja drva. Lerman svoj patriotizam potvrđuje čestim gestama. Tako, recimo, iste godine Astronomskoj sekciji Hrvatskog

17 Gradski muzej Požega u Zbirci Dragutina Lermana (inv. broj: KH - 24) čuva fotografiju s izleta HPD-a Vijenac na Majdan snimljenu u vrlo preporodnom tonu iz koje je zaključiti kako je Lerman s lakoćom povezivao svoje društvene i poslovne odnose.

18 GŽP 21. 2. i 15. 4. 1903.

19 Obavijest Dragutina Lermana dioničarima, GMP, inv. broj 13.891.

20 GŽP 9. 5. 1903. 
naravoslovnog društva, odnosno Otonu Kučeri donira 10 kruna za otvaranje Prve hrvatske zvjezdarnice u Zagrebu na Popovu tornju. ${ }^{21}$

Zahvaljujući povoljnim kreditima Pučke banke, ali i građevinskoj tvrtki brata Ivana Lermana, raste i broj gradilišta u gradu, poput nadogradnje trećeg kata Nadbiskupskog orfanatrofija, te više privatnih kuća u središtu grada, kao i niza sitnijih zahvata na fizičkom poljepšanju grada. ${ }^{22}$

Promađarski orijentirani Glasnik županije Požeške, u to vrijeme jedine požeške novine, sa zanimanjem i ponosom, gotovo navijački iz tjedna u tjedan prate Lermanova poslovna nastojanja. Tako na Veliku Gospu 1903. godine izlazi članak s detaljnim opisom preuređenja prizemlja Lermanove nove kuće u kojem su prema ulici smještene prostorije Pučke banke d.d., a u dvorištu poslovnica Dioničkog društva Majdan. ${ }^{23}$ Lerman se s Hedvigom, ostavljajući kat kuće roditeljima, seli u iznajmljeni stan u novosagrađenoj kući pravaša stolara Hinka Stipanića, preko puta crkve svetog Lovre na glavnom trgu.

\section{Utjecaj nepovoljnih političkih okolnosti na razvoj Lermanovih gospodarskih nastojanja}

Nažalost, krajem 1903. godine likvidirana je belgijska banka La Coloniale Industriell, koja je podržavala Lermanova nastojanja s ugljenokopom, što je zasigurno bio velik šok požeškom mladom i ambicioznom Dioničkom društvu Ratkovica, što je zahtijevalo i prve žrtve ${ }^{24}$.

Nije trebalo čekati dugo; već na početku sljedeće, 1904. godine počinju i prvi napadi neistomišljenika na Lermana, intonirani političkom, sve zahuktalijom situacijom oživljavanja nacionalne svijesti i borbe protiv mađarizacije. Unatoč pravaški orijentiranom ravnateljstvu Pučke banke, kao i svim ostalim vidnim nastojanjima za dobrobit grada Požege i njegovih stanovnika, u osječkom dnevniku Narodna obrana anonimnim člankom požeškog dopisnika, uz gradonačelnika Cirakija, otvoreno je prozvan i Lerman kao jedan od onih koji su političko razočaranje jer ne brane hrvatske narodne interese. Apostrofiran je kao mađaron koji se previše druži sa Židovima, neodlučni slabić sklon aristokraciji u kojoj se govori njemački, kao nedovoljno obrazovana osoba koja šuti o političkim nepravdama. ${ }^{25}$ Možda je bilo najpametnije prešutjeti taj uvredljivi članak i nastaviti s realizacijom vlastitih poslovnih vizija, ali duboko povrijeđeni Lerman dva dana poslije istim novinama šalje svoj odgovor. Njegov odgovor i danas

21 GŽP 2. 5. 1903.; Oton Kučera između 1886. i 1892. godine radio je kao profesor u požeškoj Gimnaziji sagradivši tada u Požegi prvu školsku zvjezdarnicu u Hrvatskoj.

22 GŽP 8. 8. 1903.

23 GŽP 15. 8. 1903.

24 Lerman se s vremenom odrekao svoje plaće u Dioničkom društvu Ratkovica, kao i drugih naknada vezanih za "društvene agende“. - GMP, inv. broj 13.891.

25 Narodna obrana, 12. 1. 1904. 
možemo iščitati kao proklamaciju političkog i gospodarskog zdravog razuma koja u doista teškim okolnostima političko podvojenog društva poziva na jedinstvo kako građana Požege tako i cijele Hrvatske, posebice Hrvata. Lerman iznosi svoj životni stav da se energija različitih političkih uvjerenja ne smije rasipati na objede i podvaljivanja nego da je treba sakupiti u radu za opći napredak (Kolar, 2002: 154).

Požega je odraz cjelokupne društvene i vrlo komplicirane političke situacije u Hrvatskoj početkom stoljeća u kojoj sve više jača otpor prema mađarskoj dominaciji $\mathrm{u}$ korist zapuštenih hrvatskih interesa. Nakon dvadeset i tri godine vođenja grada, sve glasnije i sve žešće napadani mađaronski gradonačelnik Franjo Ciraki u srpnju 1904. godine odlazi u mirovinu. ${ }^{26}$ Nekako u isto vrijeme pravaški orijentirani Požežani 24. srpnja 1904. osnivaju Hrvatsku narodnu tiskaru (Jakić, 1977: 484) te pokreću i vlastiti tjednik Narod kao oponent prorežimskom Glasniku županije Požeške.

Godine 1904., dolaskom na čelo grada Eduarda Kürschnera i njegova zamjenika dr. Mije Reinera, koji su bili skloni Lermanovim poslovima, počinje nova faza u životu grada Požege isprepletena vrlo složenim političkim, društvenim te obiteljskim odnosima.

Dvije godine poslije, situacija se na političkoj sceni zaoštrava, što se uvelike odražava na Lermanove poslove. Prve političke trzavice u gradu već se osjećaju na početku godine pri organiziranju velike zabave u čast projugoslavenski, dakle narodnjački, orijentiranog biskupa Strossmayera. Čast predsjedanja Odborom za sakupljanje sredstava za spomenik Strossmayeru dobila je Hedviga Lerman kao supruga čovjeka koji se s njim godinama dopisivao. ${ }^{27}$ Fran Barac, gimnazijski katehet i prefekt kolegija u Požegi od veljače 1895. do konca 1909. godine, inače dobar Lermanov prijatelj ${ }^{28}$ (Zvonar, 2007: 60), odbija tiskati svoj govor Strossmayeru u čast, „,jer su mnogi protiv obilježavanja obljetnice ${ }^{/ 29}$.

Pred nadolazeće izbore za Hrvatski sabor u gradu se osjeća sve veći animozitet. Sve je veći broj uvreda koje se na sudu procesuiraju građanskim parnicama, poput one kojom je Židov Lavoslav Klein, ravnatelj Tiskare Lavoslava Kleina, tužio za uvredu poštenja Josipa Fishera, oporbenjaka i ravnatelja Hrvatske narodne tiskare. ${ }^{30}$ Oporbenjaci počinju vrlo agilno agitirati za izbor domaćeg čovjeka u Trgovačkojobrtničkoj komori u Osijeku koji bi se konačno na hrvatskom jeziku trebao brinuti o interesima požeških trgovaca i obrtnika. ${ }^{31}$

26 Narodna obrana, 9. 7. 1904.

27 Narod, 13. 1. 1906.

28 Na Lermanov nagovor Fran Barac, uz njegov, i sam sadi veliki novi vinograd.

29 Narod, 24. 2. 1906.

30 Isto

31 Narod, 17. 3. 1906. Tekst na naslovnici vrlo se oštro obračunava s činjenicom da obrtnici i trgovci do tada nisu uopće izlazili na izbore te da je u osječkoj komori najčešće kao predstavnik završavao netko iz redova tek doseljenih građana, bez znanja hrvatskog jezika, potpuno nezainteresiran za dobrobit Požege i Hrvatske. 
Svaki Lermanov korak vezan za napredovanje procesa osnivanja tvornica u Majdanu znakovito i navijački počinje pratiti Narod, gradske oporbene novine, promičući i sve druge Lermanove poslovne aktivnosti. Tako u nekoliko brojeva, uz veliki oglas Hrvatske narodne tiskare, uvijek na istoj stranici stoji jednako velik oglas Lermanove Pučke banke ${ }^{32}$. Novine Narod hvale i osnivanje Novčanog zavoda u Kutjevu na inicijativu pravaški orijentiranog baruna Turkovića, koji u požeški kraj kao prvog oporbenog pravaškog kandidata za predstojeće izbore protiv vladina mađaronskog kandidata Kürschnera dovodi dr. Božu Vinkovića. U Kutjevu je naime Seljačka udruga, želeći pomoći seljacima, odlučila prenijeti svoje poslovanje na Pučku banku d.d. u obliku podružnice, drugim riječima, Lerman pomaže Turkovićevim pravaškim nastojanjima da se pomogne seljacima protiv bogataških zelenaša. ${ }^{33}$

Iako je politička situacija bila krajnje nepredvidiva, Lerman viziju budućnosti Majdana vidi dalje širenjem prema tvornicama koje bi trebale zaposliti dodatnih pedesetak radnika. Naime, zahvaljujući ugljenom prahu kao nusproduktu vađenja ugljena, Lerman zaključuje da je nužno podići tvornicu za proizvodnju briketa, puno jeftinijeg ogrjeva, prvu takvu u Hrvatskoj i Slavoniji. Predviđanja su da bi se ugljena prašina, Bogom dana sirovina, mogla iskoristiti u obećavajućih 1.200 vagona briketa na godinu. Jednako tako, zahvaljujući Lermanovim neumornim istraživanjima, bečki Muzej za umjetnost i obrt ustanovio je neospornu kvalitetu crne boje koju su ratkovački kemičari prema jedinstvenom receptu u svijetu uspjeli dobiti iz ugljena praha, pa tako smisao dobiva i tvornica boje. ${ }^{34}$

Nastavljajući prema zacrtanim planovima, Lerman je 18. travnja 1906. organizirao dvije osnivačke skupštine za dva nova dionička društva, Prve hrvatske tvornice briketa d.d. te Tvornice boja Nerosin d.d., kojima su utemeljitelji i ravnatelji bili on i Bernard Schwartz. ${ }^{35}$

S obzirom na parlamentarne izbore koji su se imali održati 3. svibnja, krajem travnja 1906. osjeća se vrhunac netrpeljivosti u gradu među onima koji podržavaju gradonačelnika Eduarda Kürschnera kao kandidata režimske Narodne stranke i dr. Bože Vinkovića, oporbenjaka i kandidata združene opozicije. Osobnu refleksiju cijele situacije možemo pratiti iz Cirakijeva dnevnika. Ustvrđujući kako su Turkovići i cijeli kutjevački kraj protiv Kürschnera, iako je u većini dioničkih društava Lermanova desna ruka, Cirakiju kao bivšem gradonačelniku i dobrom poznavatelju političkih prilika u gradu nije jasno kako to da je protiv njega i cijela Pučka banka te Hrvatska narodna tiskara (Ciraki, 2004: 137) ${ }^{36}$.

\footnotetext{
Narod, 27. 3. 1906.

Narod, 17. 3. 1906.

Narod 24. 3. 1906.

Narod 21. 4. 1906.

${ }^{36}$ Jednako tako bilo je teško zamisliti da Josip Fisher, računovođa Pučke banke i ravnatelj Hrvatske na-
} 
Možemo zamisliti koliko je Lermanu bilo teško i naporno balansirati u krajnje uzavreloj situaciji između obitelji, prijatelja i poslovnih suradnika, među kojima je silom prilika bilo i onih mađaronski orijentiranih, dakle interesno vezanih za službenu državnu opciju, ali pravaških, koalicijskih, oporbeno raspoloženih ${ }^{37}$. To objašnjava i činjenicu da je otišao iz grada na nekoliko dana "da se ukloni komešanju“ (Ciraki, 2004: 137).

Parlamentarni su izbori, kako na nacionalnoj, tako i na lokalnoj razini, donijeli veliko iznenađenje, jer je prvi put pobijedila oporba u vidu Hrvatsko-srpske koalicije i pravaša, dakle u Požeškoj županiji pobijedili su u šest od osam kotara, uključujući i grad Požegu. U svakom slučaju izbori za Sabor u maloj su sredini kao što je požeška donijeli veliko oduševljenje među narodom, ali i velike potrese u društvu, o čemu svjedoči Narod, novine sada pobjedničke opcije ${ }^{38}$. Na nesreću za Lermana, izbori nisu donijeli mir i stabilnost.

U srpnju 1906. gori tavan stare klaonice sa sušenim biljem politički angažiranog uglednog stolara Hinka Stipanića ${ }^{39}$, a krajem godine vatra zahvaća Lermanovu tvornicu boja Nerosin, spašenu samo prisebnošću osoblja koje je brzo evakuiralo eksplozivne tvari, tako da je stradao samo krov uz 600 kruna štete. ${ }^{40}$

Razni interesi svakako su htjeli naštetiti Pučkoj banci, koja te krizne politički uzavrele 1906. godine doživljava vrhunac svog poslovanja. Dionička glavnica podignuta je na 200.000 kruna s mogućnošću povišenja na milijun, a zadovoljni dioničari podijelili su dividende od čak $8 \%$ (Kolar, 1996: 18). Prema mišljenju povjesničarke Mire Kolar, Lerman u duhu svoga uvjerenja čini politički nesmotren potez i prihvaća prijedlog tajnika Hrvatskog trgovačkog doma iz Zagreba (buduće zagrebačke burze) da se osnuje podružnica u Požegi. S obzirom na to da je Hrvatsko-srpska koalicija željela jednu burzu, i to onu postojeću u Beogradu, njezini su pristaše činili sve, osvećujući se Lermanu, da osujete ideju osnivanja zagrebačke burze (Kolar, 1996., 18). Tako godinu dana prije u Požegi osnovana Srpska banka svojim poslovnim nastojanjima od sada ide na direktnu štetu Pučke banke, a na požeško se tržište uvozi jeftino drvo, što svakako šteti Lermanovu bratu Ivanu, vodećem građevinaru u gradu. Ohrabren okolnostima međusobnog

rodne tiskare, otvoreno agitira protiv Kürschnera, s kojim je bio prijatelj i dijelio upravljanje HPD-om Vijenac. Ipak, Kempf - pišući o Eduardu Kürschneru - napominje da je od 1906., dakle poslije njegove propale kandidature za sabor, „,odlučno pripadao netom stvorenoj Hrvatsko srpskoj koaliciji koja je onemogućila i srušila daljnji opstanak mađaronske stranke“. (Kempf 1996: 186)

37 7. siječnja 1907. Reiner i Lerman su vjenčani kumovi Kürschneru, kojega vjenčava Fran Barac. Dakle u jeku političkih previranja tim događajem zajedno su povezana dva mađarona i dva oporbenjaka. (Ciraki 2004: 178)

38 Narod, 5. 5. i 19. 5. 1906.

39 Narod, 7. 7. 1906.

40 Narod, 13. 12. 1906. Ciraki u nadnevku (21. 12. 1906.) spominje da je nastradao Bernard Schwartz, kojega je preko lica ošinuo remen koji je nenadano popustio na jednom stroju. (Ciraki 2004: 176) 
političkog istrebljenja, Schmidt, blagajnik Pučke banke, bježi s pokradenim novcem banke u Ameriku. ${ }^{41}$

Za izbor u Trgovačko-obrtničkoj komori u Osijeku, požeško građanstvo u Hrvatsko-srpskoj koaliciji kao svoga kandidata izabralo je Lermana ${ }^{42}$, ali je njegov izbor zbog belgijskog državljanstva Grad odbio potvrditi. ${ }^{43}$

Ipak, zahvaljujući Lermanovim povoljnim kreditima, Požega je 1907. godine i dalje veliko gradilište, čemu svjedoči umirovljeni gradonačelnik Ciraki, koji je u kolovozu obišao čak njih sedam (Ciraki, 2004: 212). No financijska konstrukcija koja održava sve Lermanove poslovne pothvate polako se urušava i on čini sve da je spasi. U travnju piše očajno pismo dioničarima Majdana kojima detaljno obrazlaže sva postignuća, ali i prirodne te tehničke probleme koje su stvorile nevolje stvaranja obećanog kapitala. Pozivajući se na patriotske namjere društva, moli ih da ne odustaju: „Molim dakle gg dioničare da unatoč poteškoća koje smo do sada susreli ne klonu povjerenjem. Neka crpe snagu u pomisli da je zadaća u našoj domovini podići industriju vanredno teška. ${ }^{.44}$

U svibnju 1907. godine Lerman je s prijateljem i kumom Bernardom Schwartzom osnovao Banku za trgovinu i promet koja se razvila iz Bankarske radnje Bernarda Schwartza i Zdenka Spitzera ${ }^{45}$. Teško je ne spomenuti da je Lerman, kao ravnatelj novoosnovane banke, poslije skupštine sve počastio dobrima iz svog podruma. ${ }^{46} \mathrm{I}$ dok Mira Kolar smatra da je to novo ravnateljsko mjesto trebalo poslužiti Lermanu kao rezerva tada već ugroženog mjesta u Pučkoj banci (Kolar, 1996: 21), vjerovati

${ }_{41}$ Kako bi namirio taj gubitak, Lerman nikada nije prodao dobro od 700 jutara u Jakšiću koje je kao miraz donijela Hedviga, kako to navodi Zlata Kolarić Kišur (Kolarić Kišur 1992: 36). Prema izvatku iz zemljišnih knjiga, zemlju u Jakšiću koju je dr. Mijo Reiner još 1904. godine kupio za svoju kćer, vjerojatno kao sigurnost kada su počeli prve objede i nesigurnosti u poslovima, prenio je na nju četiri godine poslije, 1908. godine, kada je bilo vidljivo da u požeškim političkim okolnostima Lermanovi poslovi ne mogu izaći na dobro. Tek 1910. godine, dakle nekoliko mjeseci poslije bankrota Pučke banke i Lermanova odlaska iz Požege, kako bi je spasila od mogućih vjerovnika, jakšićku zemlju kupuje Hedvigina sestra Agata Zmaić, da bi je za nekoliko mjeseci prenijela nazad na Hedvigu, koja ju je prodala tek 1912. godine. Zahvaljujem na susretljivosti i pomoći Općinskom sudu - Zemljišnoknjižnom odjelu, te Andreji Vojnić.

42 Narod, 12. 5. 1906.

43 Narod, 26. 5. 1906.

44 Obavijest Dragutina Lermana dioničarima, inv. broj 13.891.

45 B. Schwartz i Z. Spitzer 1900. godine započeli su objavljivati prvi moderni hrvatski obavještajnik o hrvatskom gospodarstvu (1900. - 1903.), što su danas rijetki i dragocjeni izvori. (Kolar 1996: 21) Schwartz se 1905. godine kao židov pokrstio (Lerman mu je bio kum) i oženio se Tonkom, kćeri županijskog nadinženjera Erbena, što je utjecalo i na promjene vodstva i reorganizaciju poslovanja u smislu osnivanja nove banke.

46 Narod, 9. 5. 1907., Ciraki, s obzirom na to da je i sam bio vinogradar koji je, iako imućan, tek za četiri godine uspio obnoviti svoj vinograd, pod nadnevkom 26. 3. 1908. znakovito spominje nove Lermanove nasade u vinogradu koji graniči s njegovim, uz napomenu da je morao „silni novac u taj posao uložiti“. (Ciraki 2004: 254) 
je da je novu banku osnovao isključivo radi potreba premoštavanja krize u drugim dioničkim društvima, posebno onima vezanim za ugljenokop.

Unatoč svim zakulisnim igrama, podmetanjima i pričama koje su se širile, Lerman je još uvijek bio poštovan u gradu. Vrhunac društvenog publiciteta Lermanovi doživljavaju u povodu 25. obljetnice HPD-a Vijenac, kada je Hedviga Lerman za Veliku Gospu 1907. godine kao kuma zastavi doživjela posebne počasti (Kempf, 1910: 711-714).

\section{Privatni i poslovni krah Dragutina Lermana kao rezultat nepovoljne političke situacije}

U svibnju 1907. godine umire Dragutinov stric Josip Lerman ${ }^{47}$, koji mu je uvijek bio velika podrška, a u travnju 1909. godine otac. ${ }^{48}$ Između toga 1908. godina za Lermana je iznimno teška. Nastojanjima Hrvatsko-srpske koalicije, koja želi osujetiti ideju bana Pavla Raucha o gospodarski stabilnoj i industrijski prosperitetnoj Hrvatskoj u okviru Monarhije (Kolar, 1998: 80), Srpska banka jača, pa je 1908. godina vrlo slaba godina za Pučku banku, dok Banka za trgovinu i promet posluje s gubitkom i doživljava nakon kratkog poslovanja krizu i kolaps (Kolar, 1996: 21). ${ }^{49}$

Društveno-politička situacija u gradu Požegi i dalje je osjetno napeta. Svega deset dana prije spomenute skupštine Banke za trgovinu i promet kojom je osujećen još jedan Lermanov pokušaj da spasi započete poslove industrijalizacije požeškoga kraja, dakle 19. prosinca 1908., noćni požar zahvaća posve novu kuću politički angažiranog Hinka Stipanića u kojoj su smještene Hrvatska knjižara i tiskara i Lermanov stan. Kuća je gotovo do temelja izgorjela sa svom robom Hrvatske knjižare i tiskare te Lermanovim dragocjenostima iz Afrike, uključujući i pisma brojnih odličnika iz afričkog perioda. ${ }^{50}$ Kolateralne su žrtve tog požara, za koji se nikada nije ustanovio stvarni uzrok, trgovina delikatesa Kolomana Reittera, iz čijeg se skladišta navodno i proširio požar, te stan urara, draguljara i optičara Ingnjata Bauera, koji je, po novinskim napisima, jedva izvukao živu glavu i nedugo nakon toga s obitelji se odselio iz grada. Da je taj požar buknuo u kontekstu netrpeljivosti pristaša politički zaraćenih opcija i njihovih frakcija, govori nam niz pojedinosti, poput izvještaja sa sjednice Gradskog poglavarstva 28. prosinca 1908. na kojoj je hitno, 7 : 10, usvojen prijedlog člana Vladimira Goršetića da Grad stornira sve narudžbe i aktivnosti vezane za Tiskaru i knjižaru Lavoslava Kleina, jer nije htjela prodati papir potreban za rad izgorjele, konkurentske i opozicijske Hrvatske tiskare. ${ }^{51}$

\footnotetext{
GŽP 18. 5. 1907.

GŽP 10. 4. 1909.

49 GŽP 2. 1. 1909: Na prvoj redovitoj skupštini 29. prosinca 1908. jednoglasno je razriješeno cjelokupno ravnateljstvo i nadzorni odbor nove Banke za trgovinu i promet, a Schwartz se poslije svih neuspjelih poslova s Lermanom seli iz Požege.

50 GŽP 19. 12. 1908.

51 GŽP 2. 1. 1909.
} 
Ipak, u veljači 1909. godine razboriti Kürschner ukida zaključak vezan za ignoriranje i opstrukciju Tiskare Lavoslava Kleina te, unatoč protivljenju nekih članova Poglavarstva, $u$ interesu grada organizira deputaciju kod bana Raucha, koji Požegi daje potporu od 100.000 kruna. ${ }^{52}$ Rat se nastavlja i dalje, osobito preko novina, pa se tako zagrebačke, mađaronske novine Ustavnost sada obrušavaju na aktualnog gradonačelnika Kürschnera optužujući ga da posluje puno lošije od svog prethodnika Cirakija, pa između ostalog i za to da je 40.000 kruna, gotovo polovinu Rauchove dotacije, preusmjerio kao pomoć Lermanovoj Pučkoj banci. ${ }^{53}$

Ban Pavao Rauch očito je dobro informiran o kretanjima u Požegi, koju službeno posjećuje 14. lipnja 1909. u sklopu trodnevnog posjeta Požeškoj županiji. ${ }^{54}$ Promađaronske gradske novine Glasnik županije Požeške njegov doček, naravno, prezentiraju očekivano kurtoazno, međutim - zahvaljujući sjećanju Ljuboslava Kuntarića, koji je kao dijete sudjelovao u špaliru dočeka - vidimo pravu sliku tadašnjeg odnosa građanstva prema službenoj vlasti. Uz napomenu da je Požega, osim službenih krugova, koji su silom prilika bili uz vladu, odisala pravaštvom, spominje incident prigodom kojega je netom prije prolaska automobila bana Raucha kroz špalir netko potjerao magarca uz sveopće ovacije, koje se nisu dale zaustaviti ni kada je naišao ban (Kuntarić, 1998: 331-332).

U tom kontekstu treba promatrati konačni kolaps Lermanove Pučke banke kojom se, uza sva podmetanja, uspjela održati do 26. studenog 1909., kada je proglašena likvidacija, odnosno kada ju je preuzela Prva hrvatska štedionica u Požegi kako bi se spasili dioničari, građani i njihovi ulozi.

O Lermanu po gradu kolaju ružne priče, posebno za njegova izbivanja iz grada, kada je vjerojatno išao tražiti način kako da spasi banku i ostale poslove. Tako Ciraki pod nadnevkom 6. rujna 1909. spominje kako se po gradu priča da je Lerman u Monte Carlu izgubio na kartama 3.000 forinti (Ciraki, 2004: 355). ${ }^{55}$ Činjenica je da Lerman 2. studenog $1909 .{ }^{56}$ odlazi iz Požege i da se više u nju ne vraća.

Odgovor zašto se on jedini ponio kao žrtva osudivši se na doživotno izgnanstvo iz grada koji je toliko volio i u kojemu su mu ostali svi oni za koje je najviše bio vezan istinskom odanošću (Hedviga, brat, sestre, majka, prijatelji) ${ }^{57}$, uza svu proučenu građu i izvore, za sada nam mogu dati jedino neistraženi dnevnici i pisma obitelji

52 GŽP 3. 4. 1909.

53 GŽP 1. 5. 1909.

54 GŽP 19. 6. 1909.

55 Ciraki u svom dnevniku često spominje tada društveno prihvatljivu zabavu kartanja za novce u kojima je Lerman tih godina znao gubiti povelike svote.

56 Pismo Dragutina Lermana Eduardu Kürschneru GMP, inv. broj 13.617.

57 U novopronađenoj obiteljskoj arhivi nalazi se i Lermanovo pismo obitelji iz Pariza 2. 2. 1911. u kojemu su gotovo dramatično opisani njegovi osjećaji zbog cijele situacije. 
koja smo 14. travnja 2019. detektirali u jednom obiteljskom arhivu, a koji se odnose upravo na taj nepoznati period poslije odlaska iz Požege..$^{58}$

Činjenica je da je Lermana, uza sva dionička društva (njih pet) kojima je u tom kratkom periodu nastojao ostvariti svoja poslovna nastojanja, krah Pučke banke najviše uzdrmao. Naime, bankrot banke nije nužno značio i kraj ugljenokopa Majdan i dviju tvornica u Ratkovici. ${ }^{59}$ Ipak je na određeni način Pučka banka bila odskočna daska za širenje njegovih poslovnih ideja. Njima je želio opravdati svoju reputaciju u obitelji Reiner, koja mu je ukazala povjerenje i dala ne samo svoju kćer za ženu nego i poslovnu priliku, ali i prema Požežanima, kojima je, prema brojnim izvorima, doista želio napredak.

\section{Zaključna razmatranja u svjetlu novopronađenih dnevnika i pisama Dragutina Lermana}

Nažalost, daje se naslutiti da njegov odlazak iz Požege nije bio nimalo romantične prirode kao ni njegov rastanak od Hedvige, kakvim ih opisuje Zlata Kolarić Kišur (Kolarić Kišur, 1992). U objavljenom dijelu Kreševskih dnevnika vidljivo je da se Lerman do samog kraja života nadao ponovnom susretu s Hedvigom (Lerman, 1992), koja je očito vrlo teško, nedamski, podnijela njegove političke stavove i patriotske nazore koji su ga doveli do poslovnih neuspjeha, o čemu nam svjedoče njegova pisma. ${ }^{60}$

Duboko se nadamo da ćemo, zahvaljujući susretljivosti vlasnika spomenutog obiteljskog arhiva, a na temelju skeniranja i pažljiva iščitavanja pronađene građe, u skoroj budućnosti konačno točno determinirati Lermanovo kretanje između 1909. i 1916. godine, niz pojedinosti vezanih za propale poslove u Požegi i nova nastojanja oko eksploatacije kreševskih rudnika.

Za sada tek površan pregled daje naslutiti da je, boraveći uglavnom u Parizu i Beču u vrlo teškim financijskim prilikama, osamljen pokušavao pokrenuti nove poslove kojima će vratiti svoje dugove, ali prije svega Hedvigu. Jedan od tih poslova bilo je i pokretanje zapuštenih kreševskih ugljenokopa 1911. godine (Lerman, 1992: 233), na čemu je radio do svoje smrti 12. lipnja 1918.

58 Nažalost, do ovoga trenutka nismo mogli organizirati skeniranje sve građe koja se odnosi na Lermana, ali duboko vjerujemo u susretljivost vlasnika, koji mi je u travnju 2019. godine dozvolio uvid u građu, na čemu mu iskreno zahvaljujem.

59 Tvornicom je poslije ravnao Lermanov punac, veleposjednik dr. Mijo Reiner.

${ }_{60}$ U svom pismu sestri Mici od 16. 8. 1911., koje se čuva u Franjevačkom samostanu u Požegi, Lerman joj, s obzirom na svoje iskustvo, pred udaju daje savjete kakva žena treba biti svome novom mužu: „,Za Boga, samo ga ne grdi, kada briga imao bude, jer to grozno boli. Žena sa taktom učinit će si iz čovjeka druga i prijatelja, kojoj će svu svoju duševnu sklonost pokloniti, dočim će si ga otuđiti, ako mu samo slaboće ističe, bez da sposobnosti uvaži." 
U očekivanju produžavanja koncesije za kreševske rudnike, veći dio 1915. godine proveo je kod sestre Milice u Sibinju trpeći sva poniženja koja je morao proći radeći najniže poslove za šogora Stjepana Damića, sestrina drugog muža. Jednako tako isti dnevnik potvrđuje (Kolarić Kišur, 1992: 53-57) i emotivnu, nikada ostvarenu, romantičnu privrženost puno mlađoj Adeli Mazuth, prijateljici nećakinje koja ga je osvojila utješnim slušanjem i blagošću za vrijeme tog, po njemu, najgoreg razdoblja u dotadašnjem životu.

Nakana ovoga rada jest da potakne na detaljnije istraživanje ekonomskih i političkih prilika u Požegi krajem 19. i početkom 20. stoljeća kako bi se dokraja razjasnila Lermanova gospodarska nastojanja, vrlo važna za požeški kraj. Jednako se tako nadamo da će ovaj rad utvrditi potrebu i otvoriti mogućnost pristupa te konciznog istraživanja spomenute obiteljske arhive.

\section{Literatura}

Ciraki, Franjo (2004), Bilješke i zapisci. Požega. Društvo hrvatskih književnika, ogranak slavonsko-baranjsko-srijemski.

Jakić, Tomislav (1977), Požeške štamparije i tiskare. U: Požega 1227-1977. Marijan Strbašić (ur.), Slavonska Požega: Skupština općine Slavonska Požega i Odbor za proslavu 750 godišnjice grada Slavonske Požege, str. 482-485.

Kempf, Julije (1910), Požega zemljopisne bilješke iz okoline i prilozi za povijest slobodnog $i$ kraljevskog grada Požege i Požeške županije. Požega.

Kempf, Julije (1996), Moja Požeška sjećanja. Požega. Matica hrvatska, ogranak u Požegi.

Kolar, Mira (1996), Požeško bankarstvo do kraja Drugog svjetskog rata. Zlatna dolina, II (2) Požega, str. 7-29.

Kolar, Mira (1998), Požeška županija za banovanja Pavla Raucha s posebnim osvrtom na grad Požegu (1908. - veljača 1910.). Zlatna dolina, IV (1), str. 59-87.

Kolar, Mira (2002), Poruka Dragutina Lermana iz 1904. godine. Zlatna dolina, VII (1), str. 151-159.

Kolarić Kišur, Zlata (1992), Čovjek koji je vjerovao u svoju sreću. Zagreb. Znanje.

Kuntarić, Ljuboslav (1998), Djetinjstvo (ulomci). Zlatna dolina, str. 332-341.

Lerman, Dragutin (1989), Afrički dnevnik. Zagreb. Grafički zavod Hrvatske.

Lerman, Dragutin (1992), Kreševski dnevnici. Zagreb. Znanje.

Zvonar, Ivica (2007), Fran Barac i Bogoslovska smotra. Bogoslovska smotra, Zagreb, str. 157-180. 


\section{Izvori}

Imenovanje Dragutina Lermana generalnim povjerenikom, inv. broj: 13.639, Zbirka Dragutina Lermana, Računalni inventarni program M++, Gradski muzej Požega (GMP).

Pisma Dragutina Lermana Eduardu Kurschneru, inv. broj 13.617 i 13.618, Zbirka

Dragutina Lermana, Računalni inventarni program M++, Gradski muzej Požega (GMP).

Pismo Dragutina Lermana sestri Mici Bendeković, arhiva Franjevačkog samostana u Požegi.

Obavijest Dragutina Lermana dioničarima, inv. broj 13.891, Zbirka Dragutina Lermana, Računalni inventarni program M++, Gradski muzej Požega (GMP).

Fotografija, Izlet članova HPD-a Vijenac s predsjednikom na Majdan, KH - 24, Zbirka Dragutina Lermana, Računalni inventarni program M++, Gradski muzej Požega (GMP).

Glasnici županije Požeške, tjedne novine, Požega.

Narod, tjedne novine, Požega.

Narodna obrana, dnevne novine, Osijek.

Izvod iz Matične knjige vjenčanih, prijepis, M-1/155-1982, Požeški Brestovac.

Izvadak iz Zemljišne knjige, prijepis, 3114/1988, Požega. 


\section{Prilozi}

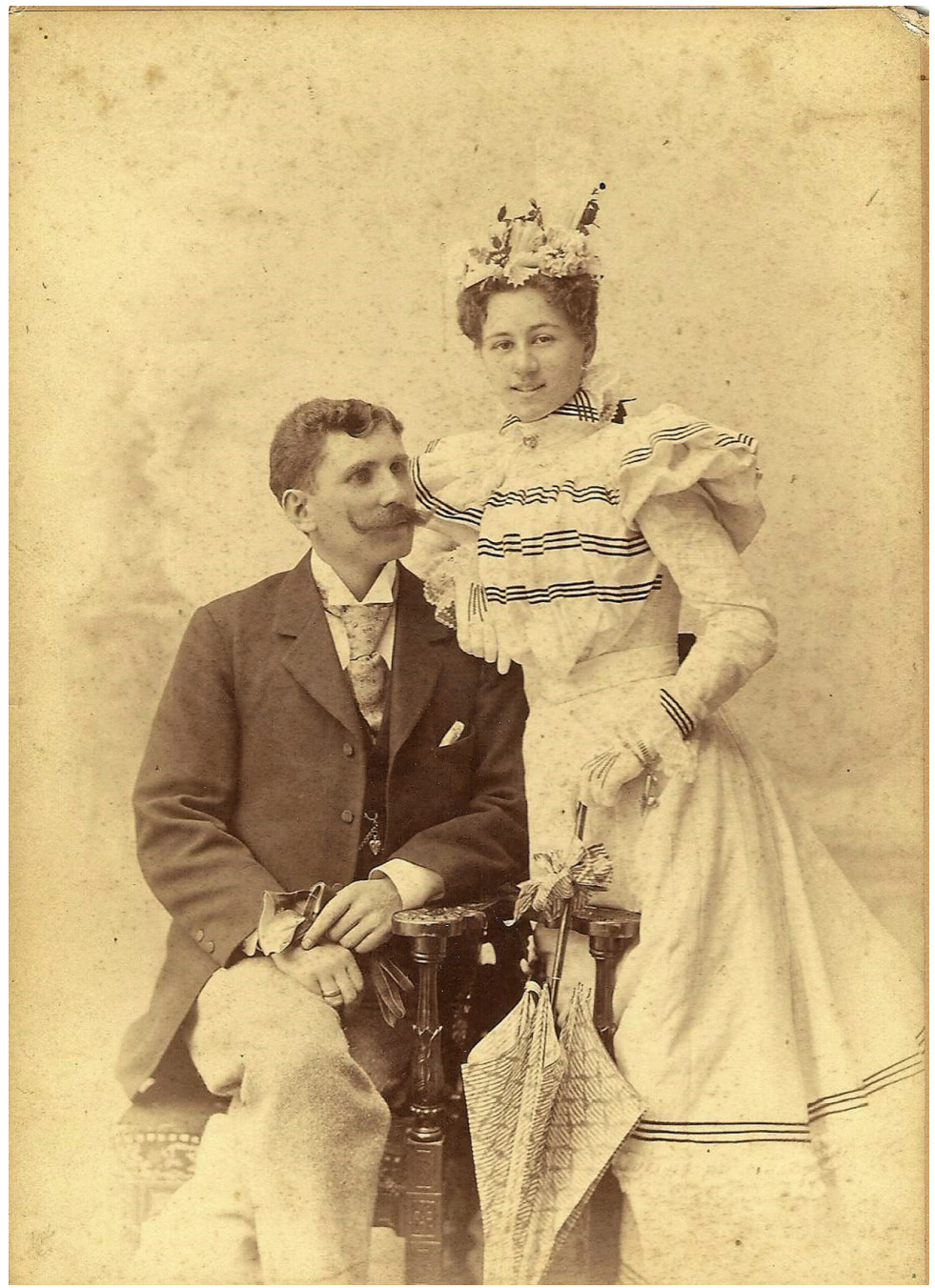

Slika 1. Dragutin i Hedviga Lerman 


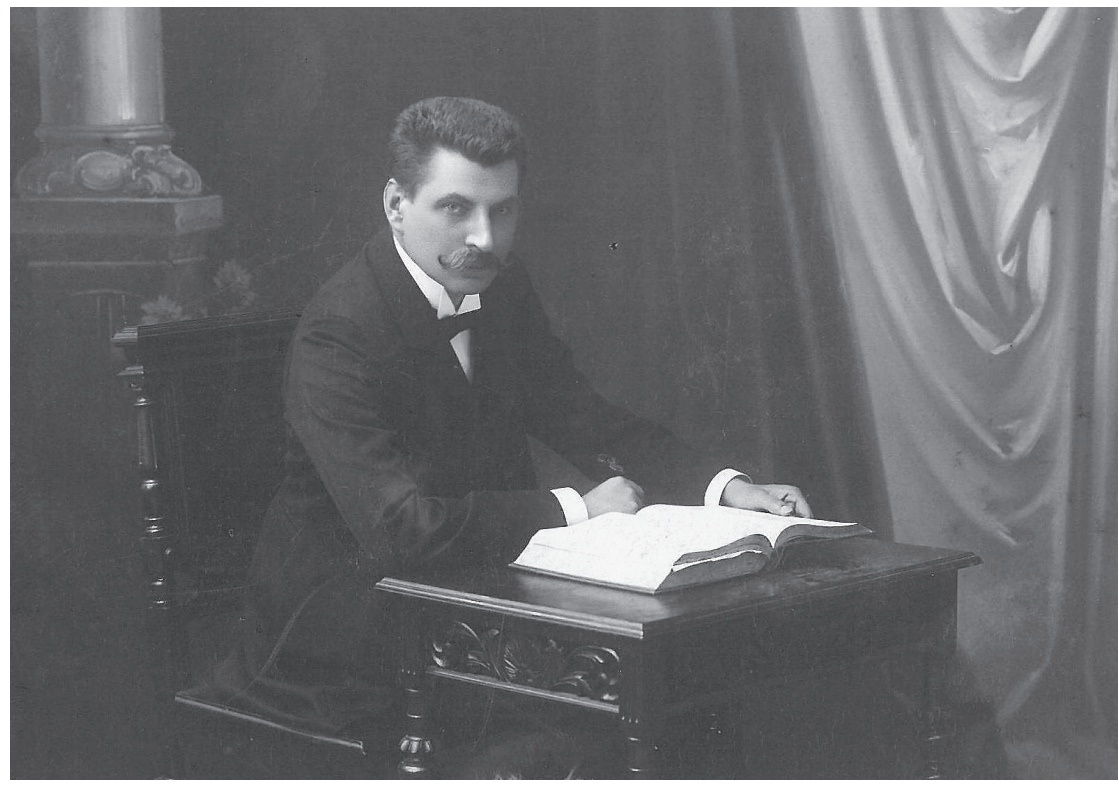

Slika 2. Dragutin Lerman u Požegi

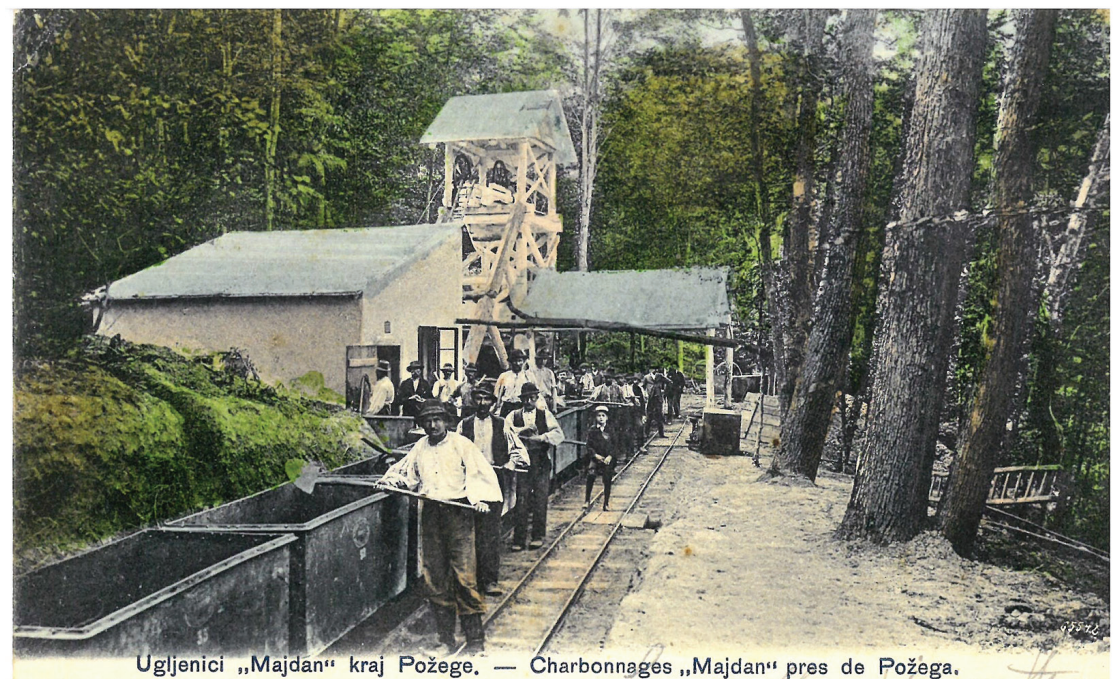

Naklada Josipa Krausza u Požegi. - Patisak zabranjen.

Slika 3. Ugljenici Majdan u Ratkovici 


\section{Dragutin Lerman in the Požega Period}

\section{Summary}

The so far acquired knowledge about Dragutin Lerman's unknown period of life and activity rests exclusively on scarce historical data, and the foreword to Lerman's Kreševo Diaries, written by Zlata Kolarić Kišur, entitled The Man Who Believed his Good Fortune.

Thanks to a more careful reading of the so far unknown material recently found in a family archive (Lerman's diaries, letters, etc.); his published diaries - The African Diary and The Kreševo Diaries; the material in custody of the Požega Museum; articles published in the local and national newspapers at the beginning of the $20^{\text {th }}$ century; and the published research by Mira Kolar, we have managed to gain a much clearer picture of Lerman's business efforts and his family life in Požega.

The paper explains Lerman's motives for leaving a successful career as the East Kwango General Commissioner in Africa and returning to Požega.

The paper further attempts to clarify the local and national political and social background not only of his success, but also of the complete collapse of his business ventures in Požega. It moreover endeavours to shed more light on the fact that Lerman, once a successful business man, suddenly became ruined and outcast from the town to the prosperity of which he had dedicated a major part of his life.

The paper may furthermore initiate research of new sources, which could particularly illuminate and offer insight into the still rather obscure years Lerman spent in exile in Europe, and his strivings to find investors for the failing investments in Požega.

Keywords: Dragutin Lerman; Požega; diary; Požega period.

Maja Žebčević Matić, dipl. etn., muzejska savjetnica

Gradski muzej Požega

Matice hrvatske 1, 34000 Požega

maja@gmp.hr 